Hydrol. Earth Syst. Sci., 17, 1681-1691, 2013

www.hydrol-earth-syst-sci.net/17/1681/2013/

doi:10.5194/hess-17-1681-2013

(C) Author(s) 2013. CC Attribution 3.0 License.

\title{
Streamflow input to Lake Athabasca, Canada
}

\author{
K. Rasouli ${ }^{1}$, M. A. Hernández-Henríquez ${ }^{2}$, and S. J. Déry ${ }^{2}$ \\ ${ }^{1}$ Department of Civil and Environmental Engineering, University of Waterloo, 200 University Ave W., Waterloo, \\ ON, N2L 3G1, Canada \\ ${ }^{2}$ Environmental Science and Engineering Program, University of Northern British Columbia, 3333 University Way, \\ Prince George, BC, V2N 4Z9, Canada \\ Correspondence to: S. J. Déry (sdery@unbc.ca)
}

Received: 4 July 2012 - Published in Hydrol. Earth Syst. Sci. Discuss.: 2 August 2012

Revised: 24 March 2013 - Accepted: 7 April 2013 - Published: 2 May 2013

\begin{abstract}
The Lake Athabasca drainage area in northern Canada encompasses ecologically rich and sensitive ecosystems, vast forests, glacier-clad mountains, and abundant oil reserves in the form of oil sands. The basin includes the Peace-Athabasca Delta, recognized internationally by UNESCO and the Ramsar Convention as a biologically rich inland delta and wetland that are now under increasing pressure from multiple stressors. In this study, streamflow variability and trends for rivers feeding Lake Athabasca are investigated over the last half century. Hydrological regimes and trends are established using a robust regime shift detection method and the Mann-Kendall (MK) test, respectively. Results show that the Athabasca River, which is the main contributor to the total lake inflow, experienced marked declines in recent decades impacting lake levels and its ecosystem. From 1960 to 2010 there was a significant reduction in lake inflow and a significant recession in the Lake Athabasca level. Our trend analysis corroborates a previous study using proxy data obtained from nearby sediment cores suggesting that the lake level may drop 2 to $3 \mathrm{~m}$ by 2100 . The lake recession may threaten the flora and fauna of the Athabasca Lake basin and negatively impact the ecological cycle of an inland freshwater delta and wetland of global importance.
\end{abstract}

\section{Introduction}

Lake Athabasca, straddling the provinces of Alberta and Saskatchewan, forms the third largest lake (by area) in northern Canada. It receives direct runoff from a large catchment area spanning $271000 \mathrm{~km}^{2}$ including the Athabasca, Fond $\mathrm{du}$ Lac, and other small river catchments. Lake Athabasca forms a large, natural reservoir of freshwater in the upper reaches of the $1.8 \times 10^{6} \mathrm{~km}^{2}$ Mackenzie River basin, thus influencing the timing and amount of pan-Arctic river discharge (e.g., McClelland et al., 2006). It is the site of the ecologically sensitive Peace-Athabasca Delta (PAD) that depends on spring flood events for freshwater recharge (Peters et al., 2006; Smith and Pavelsky, 2009; Wolfe et al., 2008a,b). The Athabasca River, the longest river entirely within Alberta, is especially important for societal needs and economic development such as for domestic water consumption and for irrigation of agricultural lands. This waterway is also important for the oil sands industry near Fort McMurray, Alberta, as bitumen extraction requires significant amounts of water that are currently being sourced from the river itself. Thus the cumulative impacts of industrial and other anthropogenic activities, in addition to climate change, are affecting the lake's water balance and surrounding ecosystem (Schindler and Donahue, 2006).

Previous studies on streamflow variability and trends in the Lake Athabasca watershed have focused on the Athabasca River itself. Summer streamflow in the headwaters of the Athabasca River declined by about $0.2 \%$ per year over the 20th century, reducing riparian groundwater recharge and imposing water deficit stress on floodplain forests (Rood et al., 2008). Further downstream, May to August streamflow declined by $33.3 \%$ from 1970 to 2003 on the Athabasca River near Fort McMurray in response to receding Rocky Mountain glaciers and lower snowpack levels (Schindler and Donahue, 2006). Abdul Aziz and Burn (2006) found strong increasing trends in the December to April flows, as well as in the annual minimum flow, in the Athabasca River system. They also reported weak decreasing trends in the early 
summer and late fall flows as well as in the annual mean flow for the Athabasca River. Woo and Thorne (2003) reported increasing variability in annual streamflow of the Athabasca River near Fort McMurray in the late 20th century. Recent sediment cores extracted from a pond adjacent to Lake Athabasca place the recent hydrological variability of the Athabasca River into a 5200 yr context (Wolfe et al., 2011). Their proxy record of water levels of Lake Athabasca shows drops between 2-4 m below the 20th century mean in the mid-Holocene that may reoccur by 2100 with continued climate change.

Despite some of these recent advances in our knowledge of the hydrology of the Lake Athabasca basin, little information exists on total streamflow input to Lake Athabasca. Previous studies have focused on the Athabasca River itself but have not investigated lake inflows from other main contributors such as the Fond du Lac River and other small rivers that collectively contribute $\sim 43 \%$ of its total input. In the current research, we investigate quantitative changes through analysis of hydrological regime variability and trends across the Lake Athabasca basin using an observational data set of streamflow. The total streamflow input to Lake Athabasca and the gauge contribution of different tributaries from 1960 to 2010 are also examined. Furthermore, the reasons and periods of decline in lake level, as well as the prospects for the future, are investigated and compared with the results found from the nearby sediment core studies. Thus the main objective of this study is to assess the changes in streamflow input to Lake Athabasca and to compare these results with recent sediment core studies in the area. In the next sections, the study area and data are introduced. Next, the methodology and hydrological regime variability and trend detection tools are explained. The results follow and the paper ends with a discussion of the implications of our work.

\section{Study site}

The Lake Athabasca basin is located between $52^{\circ} 10^{\prime} \mathrm{N}$ and $60^{\circ} 10^{\prime} \mathrm{N}$ and $100^{\circ} \mathrm{W}$ and $120^{\circ} \mathrm{W}$, covering an area of $271000 \mathrm{~km}^{2}$ in the Canadian provinces of Saskatchewan and Alberta as well as the Northwest Territories (Fig. 1). The catchment elevation varies between $3747 \mathrm{~m}$ at Mount Columbia and $205 \mathrm{~m}$ near the lake shore. The Athabasca River drains from the Rocky Mountains in Jasper National Park. Elsewhere, the landscape in the lower Lake Athabasca basin is mainly covered by ponds, black spruce forests, and to some extent agricultural lands $(\leq 5 \%)$. The basin has over 1000 lakes and ponds that support many First Nations communities. The Athabasca River is especially important for the oil sands industry as bitumen extraction requires significant amounts of water that are currently being extracted from the river itself. The future oil sands operations may extend over $140000 \mathrm{~km}^{2}$ or $20 \%$ of Alberta given projected developments (Jordaan et al., 2009). The Lake Athabasca basin includes the Peace-Athabasca Delta (PAD), which is a wetland of international importance recognized by the Ramsar Convention and UNESCO for its biologically rich delta now subject to multiple stressors (Wolfe et al., 2012). The PAD is also an important bird migration staging point and forms part of the habitat for the largest bison herd in North America (Bennett et al., 1973).

The Fond du Lac River flows from Wollaston Lake to Black Lake, and there are twenty-eight rapids or falls along the river. Up to $86 \%$ of the Athabasca-Fond du Lac river drainage area has been gauged for at least $20 \mathrm{yr}$ in the last few decades. The two largest rivers by contributing area are the Athabasca River $\left(\sim 150000 \mathrm{~km}^{2}\right)$ and the Fond du Lac River $\left(\sim 50000 \mathrm{~km}^{2}\right)$. There is also a number of smaller rivers draining into Lake Athabasca, mainly on its southern shore including the MacFarlane, Douglas, Grease, Otherside, Richardson and William rivers. The lower reaches of the Athabasca River begin at Fort McMurray, where the river is joined by the Clearwater River. During ice-jam floods, the Peace River may overflow into Lake Athabasca and act as a hydraulic barrier to lake outflow when the river level is higher than the lake level. Lake Athabasca covers an area of $7800 \mathrm{~km}^{2}$ and its mean depth is about $20 \mathrm{~m}$ (Peters and Buttle, 2010). The lake basin has long, cold winters and relatively short summers. No less than $50 \%$ of the total lake inflow occurs over May-August (Muzik, 1991). Mean annual air temperature at the nearby Fort Chipewyan meteorological station is $-1.9{ }^{\circ} \mathrm{C}$ and $59 \%$ of the annual precipitation occurs during May-September (Wolfe et al., 2008b).

\section{Data and methods}

\subsection{Data sources}

A list of the 14 gauges on the rivers and lake shore for measuring the lake level used in the present study along with their identification numbers and geographical information is summarized in Table 1. The source of the data is the Water Survey of Canada. Daily streamflow data (in $\mathrm{m}^{3} \mathrm{~s}^{-1}$ ) are extracted and compiled to form annual time series. Streamflow variability between two immediate gauges on the Athabasca River, hereafter referred to as "gauge contribution", is determined by subtracting the annual streamflow in an upstream gauge from that of the nearest downstream gauge. This helps identifying the contributions of individual reaches within the Athabasca River drainage to streamflow variability and trends across the basin. For simplicity, the total streamflow for the smaller rivers (Douglas, Grease, MacFarlane, Otherside, Richardson and William rivers) are combined to create a single annual discharge time series for the regime shift and trend analyses. The gauge on the Fond du Lac River was moved just upstream from its original location in 1963, so the records from the two gauges are spliced to form one time series of annual discharge for 1960 to 2010 while accounting 


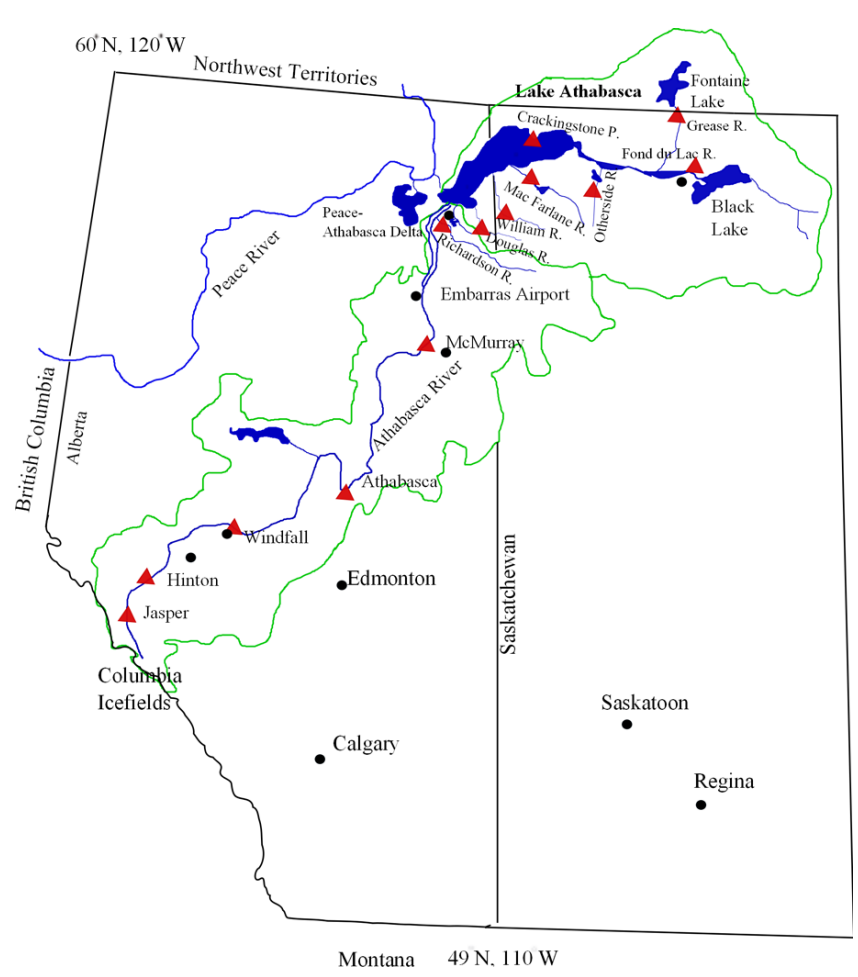

Fig. 1. Map of the Athabasca and Fond du Lac River basins and location of monitoring stations (red triangles) in the Lake Athabasca basin.

for the change in contributing area (e.g., Déry et al., 2012). Five of the gauges are on the main stem of the Athabasca River, listed from the largest to the smallest gauged area in the table. Data span the period of record up to 2010. Annual discharges are in units of $\mathrm{km}^{3} \mathrm{yr}^{-1}$ after initial analyses (e.g., cross correlations) were reconstructed to obtain the period 1960-2010 for all 13 streamflow gauges, as the records do not cover all the same periods. Time series of four gauges on the Athabasca River and the single gauges on the Stony Rapids and MacFarlane rivers with longer records are used for reconstructing the missing data for gauges on the Athabasca River and small rivers. The Fond du Lac River is used to reconstruct missing data on the Grease and MacFarlane rivers, as there is a significant correlation between overlapping records. For the other smaller rivers (Otherside, Douglas, William, and Richardson rivers), they correlate significantly with the MacFarlane River more so than with the Fond du Lac River (significant correlation level, $\rho \geq 0.67$ ). Therefore, these rivers are reconstructed using the time series recorded at MacFarlane with nearly complete data. To evaluate the level of Lake Athabasca, records of lake level near Crackingstone Point (07MC003) are implemented. The outflow weirs constructed in 1975 and 1976 have artificially increased the average annual lake level by about $0.33 \mathrm{~m}$. The original time series of lake level at Crackingstone Point has been adjusted after 1976 by subtracting $0.33 \mathrm{~m}$ from the artificially modified recorded data (PADTS, 1996).

\subsection{Methodology}

The regime detection method of Rodionov (2004) that detects significant shifts in the mean level of streamflow variations is applied in this study (http://www.beringclimate.noaa. gov/). Model outputs are lines of zero slopes representing the different regimes detected. Two factors are needed to be considered in regime shift detection: the significance level and the length of the regimes compared. The significance level (in this study $p \leq 0.1$ ) is a threshold at which the null hypothesis is rejected by the two-tailed Student $t$ test. The null hypothesis is defined so that the means of the two regimes are equal. If the significance level is low, the hydrological regime shift should be greater to be detected. In the method used in this study, a cut-off length constraint is $12 \mathrm{yr}$. If the regime length is less than the cut-off length, the probability of detection declines although the longer regimes are detected. Equal-weighed arithmetic means of the regimes are considered for different regime changes in the hydrometric gauges of the study area. We have attempted to relate the regime shifts and the trend results by conducting trend analyses on the separate "regimes" identified in the regime shift analysis. The reason we have combined the regimes and trends is that if the only change actually occurring in the data comes from the regime shifts, then the trends identified are simply artifacts of the regime shifts and not real trends. Trend analysis on the separate regimes would then be acceptable to extrapolate the trends into the future.

The non-parametric Mann-Kendall (MK) statistical test developed by Mann (1945) and Kendall (1975) has been widely used to detect trends in different environmental time series such as river discharge, rainfall, air temperature, and water quality (e.g., Burn et al., 2004; Déry et al., 2005; Abdul Aziz and Burn, 2006). The advantage of using this method for trend detection is that it is powerful in the case of non-normally distributed time series and relatively insensitive to outliers. The MK test is applied in this study to assess the significance of sub-basin trends in the Athabasca River (i.e., areas between gauges) and existing trends in the Lake Athabasca input. The null hypothesis test is conducted on different, common lengths detected, and a set of the rejected hypotheses (significant trends) are obtained. Trend detection analysis is carried out for three different analysis periods, 34, 41 and $51 \mathrm{yr}$ in duration, with each analysis period ending in the year 2010. The analysis periods link the detected regimes to the trends found in the study area. The analysis periods represent a trade-off between greater accuracy of the lake inflow time series versus greater power for the statistical tests for a longer record length. The serial correlation in the data sets is a factor that can impact the results of the MK test (von Storch, 1995). This results in the incorrect rejection of the null hypothesis of no trend, whereas the null hypothesis is actually true. One of the pre-whitening methods was proposed by Hamed and Rao (1998), in which an empirical relation is used to compute effective sample size 
Table 1. List of hydrometric gauges in the study area and corresponding discharge statistics. Discharge difference between two immediate gauges on the Athabasca River, combined gauge area for small rivers, and total lake inflow information over 1960-2010 are also provided.

\begin{tabular}{|c|c|c|c|c|c|c|c|c|c|}
\hline Code & River & Hydrometric station & $\begin{array}{l}\text { Lat. } \\
{\left[{ }^{\circ} \mathrm{N}\right]}\end{array}$ & $\begin{array}{l}\text { Long. } \\
{\left[{ }^{\circ} \mathrm{W}\right]}\end{array}$ & $\begin{array}{r}\text { Area } \\
{\left[\mathrm{km}^{2}\right]}\end{array}$ & $\begin{array}{r}\text { Mean } \\
{\left[\mathrm{km}^{3} \mathrm{yr}^{-1}\right]}\end{array}$ & $\begin{array}{r}\text { Std. Dev. } \\
{\left[\mathrm{km}^{3} \mathrm{yr}^{-1}\right]}\end{array}$ & $\begin{array}{l}\mathrm{CV} \\
{[-]}\end{array}$ & $\begin{array}{r}\text { Contribution } \\
{[\%]}\end{array}$ \\
\hline 07DA001 & Athabasca & Below McMurray & 56.8 & 111.4 & 132585 & 19.5 & 4.1 & 0.21 & 56.9 \\
\hline 07BE001 & Athabasca & Athabasca & 54.7 & 113.3 & 74602.3 & 13.2 & 3.1 & 0.23 & 38.5 \\
\hline 07AE001 & Athabasca & Windfall & 54.2 & 116.1 & 19600 & 7.4 & 1.2 & 0.16 & 22.0 \\
\hline 07AD002 & Athabasca & Hinton & 53.4 & 117.6 & 9764.8 & 5.4 & 0.7 & 0.12 & 16.0 \\
\hline 07AA002 & Athabasca & Jasper & 52.9 & 118.1 & 3872.7 & 2.7 & 0.3 & 0.10 & 8.1 \\
\hline 07LE002 & Fond Du Lac & Outlet Black Lake & 59.1 & 105.5 & 50700 & 10.0 & 1.5 & 0.15 & 29.6 \\
\hline 07LE001 & Fond Du Lac & Stony Rapids & 59.3 & 105.8 & 51800 & - & - & - & - \\
\hline 07MA003 & MacFarlane & Outlet Davy Lake & 59.0 & 108.2 & 9120 & 1.70 & 0.30 & 0.15 & 5.1 \\
\hline 07LE003 & Douglas & Near Cluff Lake & 58.3 & 109.8 & 1690 & 0.30 & 0.10 & 0.19 & 0.9 \\
\hline 07MB001 & Grease & Below Fontaine Lake & 59.5 & 106.4 & 6150 & 0.88 & 0.21 & 0.24 & 2.6 \\
\hline 07LE004 & Otherside & Outlet Mercredi Lake & 58.9 & 107.5 & 2700 & 0.54 & 0.09 & 0.17 & 1.6 \\
\hline 07DD002 & Richardson & Mouth & 58.4 & 111.2 & 2730.9 & 0.50 & 0.04 & 0.08 & 1.5 \\
\hline \multirow[t]{7}{*}{ 07MA004 } & William & Above Carswell River & 58.8 & 109.0 & 4030 & 0.63 & 0.11 & 0.17 & 1.9 \\
\hline & Athabasca & McMurray minus Athabasca & & & 57982.7 & 6.34 & 2.16 & 0.34 & 18.4 \\
\hline & Athabasca & Athabasca minus Windfall & & & 55002.3 & 5.73 & 2.20 & 0.38 & 16.5 \\
\hline & Athabasca & Windfall minus Hinton & & & 9835.2 & 2.04 & 0.71 & 0.35 & 5.9 \\
\hline & Athabasca & Hinton minus Jasper & & & 5892.1 & 2.68 & 0.40 & 0.15 & 8.0 \\
\hline & Combined & All small tributaries & & & 17300.9 & 4.57 & 0.70 & 0.15 & 13.5 \\
\hline & Total & Lake Athabasca inflow & & & 271000 & 34.06 & 5.17 & 0.15 & 100.0 \\
\hline $07 \mathrm{MC} 003$ & Lake level (m) & Crackingstone Point & 59.4 & 108.9 & 271000 & 208.78 & 0.38 & 0.00 & - \\
\hline
\end{tabular}

to remove the effect of the serial correlation. Another procedure used to account for the autoregressive parameter $\rho$ with small sample size (say $n=7$ ) is based on the assumption that the first approximation of the biased estimate of $\rho$ is inversely proportional to sample size. This is one of the prewhitening approaches that is used to remove the red noise component from time series prior to applying the regime shift detection procedure (Orcutt and Winokur, 1969; Rodionov, 2004). Since the conventional pre-whitening methods in removal of the serial correlation component from time series reduce the magnitude of the existing trend, we have applied the trend-free pre-whitening (TFPW) procedure in this study introduced by Yue et al. (2002). The TFPW method includes the following steps:

- estimation of the trend slope based on Theil (1950a,b,c) and Sen (1968);

- computation of the lag-one serial correlation coefficient of the detrended series and removal of the $\operatorname{AR}(1)$;

- combining the identified trend and the residuals;

- conducting the MK test.

In this approach, the removal of a trend component from a time series prior to pre-whitening removes the effect of the trend on the serial correlation and does not significantly influence the true lag-one autoregressive, $\operatorname{AR}(1)$.

\section{Results}

The detected regime shifts and trends, both for the recorded data at the gauges and sub-basin contribution of the gauged drainage areas, are discussed in detail in this section. Results for the Athabasca River itself are first examined, where possible discharge trends in some reaches may be compensated by changes elsewhere in the basin. Thereafter, the streamflow variability and trends in the Fond du Lac River and other lake tributaries, as well as total inflow to Lake Athabasca, are also analyzed.

\subsection{Relative contributions of Lake Athabasca inflow}

The Athabasca and Fond du Lac rivers contribute $86.5 \%$ of the annual Athabasca Lake inflow, whereas the other smaller rivers account for $13.5 \%$ of total lake inflow (Table 1). Figure 2 illustrates the temporal evolution of the relative contribution of the main reaches in Lake Athabasca inflow. The annual flow during 1988-2010 in the Athabasca River declined, which might be because the McMurray gauge experienced minimum contributions into the lake inflow in 1995-1997 and 2001-2005. The recorded time series at this gauge has the highest variability (standard deviation of $4.3 \mathrm{~km}^{3} \mathrm{yr}^{-1}$, shown in Table 1) in the study period, and the coefficient of variation, $\mathrm{CV}$, is 0.21 . In contrast, the contribution of annual flow rate along the Fond du Lac River increased during the period 1977-2010, which partially compensated the hydrological regime shift in other parts of the Lake Athabasca basin. 


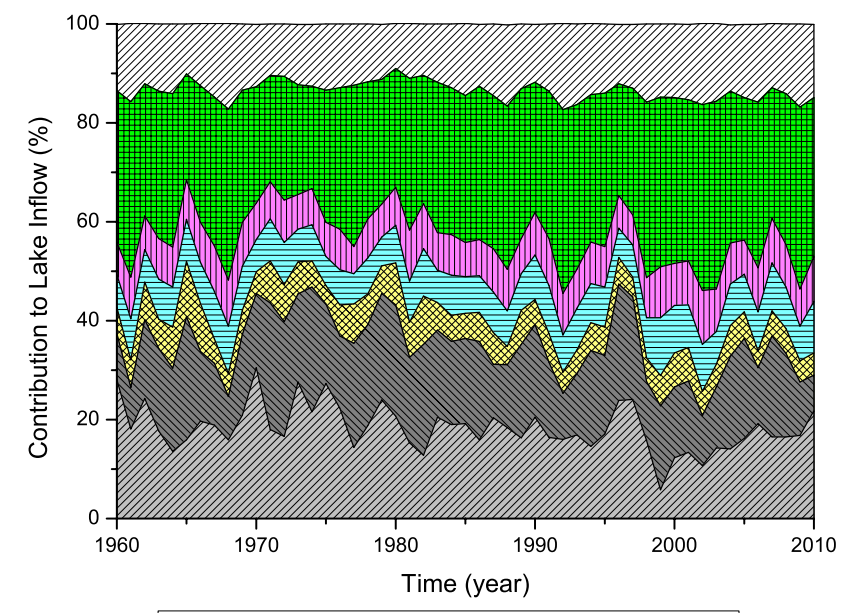

DIIIA McMurray Athabasca Windfall

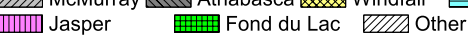

Fig. 2. Percentage of the annual contribution into Lake Athabasca inflow and hydrological regime variability in the Lake Athabasca basin over 1960-2010. There is a decline along the Athabasca River and a slight increase along the Fond du Lac River and other combined small rivers.

\subsection{Athabasca River basin}

Glacier runoff from the Columbia Icefield and other mountain glaciers as well as seasonal snowmelt from the mountain headwaters are important components of the annual water availability in the lake drainage basin (Marshall et al., 2011). The total contribution from the headwaters of the Athabasca River as recorded at Jasper amounts to $8.1 \%$ of the total lake inflow (Table 1) over 1960-2010. The MK test reveals a clear decreasing trend of $0.005 \mathrm{~km}^{3} \mathrm{yr}^{-1}$ detected for the entire study period at Jasper, while no regime shift is detected at this gauge (Fig. 3). The contribution of the headwaters in the Rocky Mountains to the lake inflow thus declined $0.27 \mathrm{~km}^{3}$ over 1960-2010 (Table 2).

The Athabasca River discharge data at Hinton show no regime shift, and for the contributing area between Hinton and Jasper, there is a slight regime drop in 1979 from $2.8 \mathrm{~km}^{3} \mathrm{yr}^{-1}$ to $2.6 \mathrm{~km}^{3} \mathrm{yr}^{-1}$. In addition, the trend for discharge data as measured at Hinton is $-0.011 \mathrm{~km}^{3} \mathrm{yr}^{-1}$, equivalent to a $0.57 \mathrm{~km}^{3}$ decline over $1960-2010$, while the area between the Hinton and Jasper gauges shows no significant trend. Athabasca River discharge data at Windfall and for the contributing area between Windfall and Hinton exhibit significant trends of $-0.033 \mathrm{~km}^{3} \mathrm{yr}^{-1}$ and $-0.022 \mathrm{~km}^{3} \mathrm{yr}^{-1}$ (both with $p$ value $=0.00$ ), respectively, with corresponding mono-regimes of $7.4 \mathrm{~km}^{3} \mathrm{yr}^{-1}$ and $2.04 \mathrm{~km}^{3} \mathrm{yr}^{-1}$. Streamflow in the Athabasca River at the Windfall gauge thus declined $1.67 \mathrm{~km}^{3}$ over 1960 2010. The gauge contribution of the drainage area between Windfall and Hinton gauges decreased by $1.11 \mathrm{~km}^{3}$ over the study period. Elsewhere on the Athabasca River,

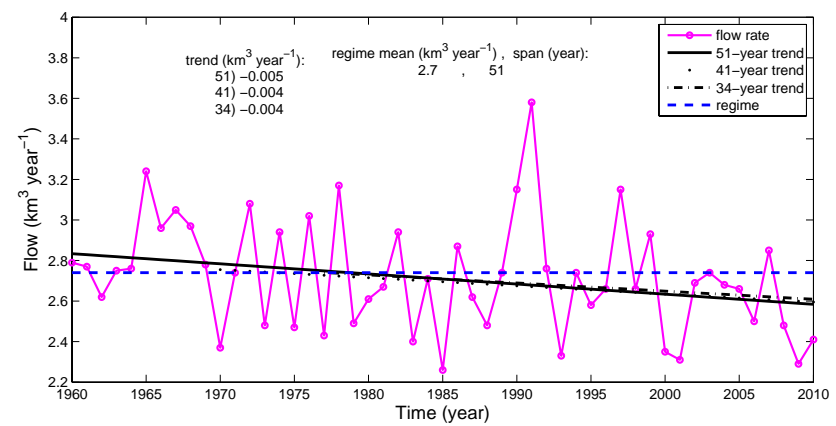

Fig. 3. Trends detected for three different analysis periods, 34, 41 and $51 \mathrm{yr}$ in duration, at Jasper. A significant trend of $-0.005 \mathrm{~km}^{3} \mathrm{yr}^{-1}$ with $p$ value $=0.03$ is detected for the period of 1960-2010.

a regime drop of $2.9 \mathrm{~km}^{3} \mathrm{yr}^{-1}$ in 1998 is detected at the Athabasca gauge (Fig. 4a). Similarly, the gauge contribution from the Athabasca drainage area between this gauge and the upstream gauge at Windfall (Athabasca minus Windfall time series) experiences a downward regime shift in 1998 (Fig. 4b). At the Athabasca gauge, there is one significant decreasing trend detected over $51 \mathrm{yr}$. The trend rate is $-0.070 \mathrm{~km}^{3} \mathrm{yr}^{-1}$, equating to a $3.55 \mathrm{~km}^{3}$ volume loss in the Lake Athabasca input. The trend analysis in the period of 1998-2010 demonstrates a relation between the regime change in 1998 and a stronger trend afterward. The gauge contribution of the drainage area between the Athabasca and Windfall gauges decreased $2.06 \mathrm{~km}^{3}$ over the study period.

The most downstream gauge on the Athabasca River in this study is located near Fort McMurray (see Fig. 1) and is thus a good indicator of the total contribution of the Athabasca River to Lake Athabasca inflow. There is a large downward regime shift of $5.4 \mathrm{~km}^{3} \mathrm{yr}^{-1}$ over 1998 2010 at the McMurray gauge on the Athabasca River (Fig. 5a). The gauge records and the gauge contribution of the Athabasca River between the McMurray and Athabasca gauges (Fig. 5b) show decreasing trends of $-0.145 \mathrm{~km}^{3} \mathrm{yr}^{-1}$ $(p$ value $=0.02)$ and $-0.056 \mathrm{~km}^{3} \mathrm{yr}^{-1} \quad(p$ value $=0.05)$, equivalent to a $7.38 \mathrm{~km}^{3}$ reduction in flows on the Athabasca River at the McMurray gauge with a contribution of $2.85 \mathrm{~km}^{3}$ for the area between the McMurray and Athabasca gauges to that trend over 1960-2010 (Table 2). Unlike the drainage area between the Athabasca and Windfall gauges, the time series of discharge difference between McMurray and Athabasca representing the gauge contribution of the area between these two gauges shows no regime shift.

\subsection{Fond du Lac River basin and other tributaries}

After the Athabasca River, the Fond du Lac River provides the largest contribution to total annual Lake Athabasca inflow at $29.6 \%$ (Table 1). No regime shift is detected in Fond du Lac River, and the detected trends for different analysis 
Table 2. Total discharge variability in the different tributaries across the Lake Athabasca basin and detected trends for three different, common analysis periods, 34, 41 and $51 \mathrm{yr}$ in duration, with associated discharge changes in comparison to the long-term average. Note that bold values denote significant trends ( $p$ values are shown in parentheses) and that Lake Athabasca level trends and change are in units of $\mathrm{m} \mathrm{yr}^{-1}$ and $\mathrm{m}$, respectively.

\begin{tabular}{|c|c|c|c|c|c|c|c|}
\hline No. & Station & $\begin{array}{l}\text { Period } \\
\text { of } \\
\text { record }\end{array}$ & $\begin{array}{l}\text { Trend } 1 \\
1960-2010 \\
{\left[\mathrm{~km}^{3} \mathrm{yr}^{-1}\right]}\end{array}$ & $\begin{array}{l}\text { Trend } 2 \\
1970-2010 \\
{\left[\mathrm{~km}^{3} \mathrm{yr}^{-1}\right]}\end{array}$ & $\begin{array}{l}\text { Trend } 3 \\
1977-2010 \\
{\left[\mathrm{~km}^{3} \mathrm{yr}^{-1}\right]}\end{array}$ & $\begin{array}{r}\text { Change } \\
1960-2010 \\
{\left[\mathrm{~km}^{3}\right]}\end{array}$ & $\begin{array}{r}\text { Change } \\
1960-2010 \\
{[\%]}\end{array}$ \\
\hline 1 & Below McMurray & 1957-2010 & $-\mathbf{0 . 1 4 5}(0.02)$ & $-\mathbf{0 . 2 2 9}(0.00)$ & $-\mathbf{0 . 2 1 6}(0.06)$ & -7.38 & -37.9 \\
\hline 2 & Athabasca & 1913-2010 & $-\mathbf{0 . 0 7 0}(0.02)$ & $-\mathbf{0 . 1 2 4}(0.00)$ & $-\mathbf{0 . 1 3 8}(0.02)$ & -3.55 & -26.9 \\
\hline 3 & Windfall & 1960-2010 & $-\mathbf{0 . 0 3 3}(0.00)$ & $-\mathbf{0 . 0 3 3}(0.00)$ & $-\mathbf{0 . 0 3 9}(0.06)$ & -1.67 & -22.6 \\
\hline 4 & Hinton & $1961-2010$ & $-\mathbf{0 . 0 1 1}(0.09)$ & -0.004 & -0.005 & -0.57 & -10.6 \\
\hline 5 & Jasper & 1970-2010 & $-\mathbf{0 . 0 0 5}(0.03)$ & -0.004 & -0.004 & -0.27 & -10.2 \\
\hline 6 & Fond Du Lac & 1946-2010 & -0.002 & 0.021 & -0.006 & -0.10 & -1.0 \\
\hline 7 & MacFarlane & 1967-2010 & -0.002 & 0.002 & 0.003 & -0.10 & -6.0 \\
\hline 8 & Douglas & 1975-2010 & -0.001 & 0.000 & 0.000 & -0.03 & -11.3 \\
\hline 9 & Grease & 1973-1995 & 0.000 & 0.003 & 0.000 & 0.00 & 0.0 \\
\hline 10 & Otherside & 1976-1995 & 0.000 & 0.001 & 0.001 & -0.01 & -2.6 \\
\hline 11 & Richardson & 1970-2010 & 0.000 & 0.000 & 0.001 & 0.00 & 0.0 \\
\hline 12 & William & 1976-1995 & -0.001 & 0.000 & 0.000 & -0.05 & -7.8 \\
\hline 13 & McMurray-Athabasca & $1957-2010$ & $-\mathbf{0 . 0 5 6}(0.05)$ & $-\mathbf{0 . 0 9 2}(0.03)$ & -0.061 & -2.85 & -45.0 \\
\hline 14 & Athabasca-Windfall & 1960-2010 & $-\mathbf{0 . 0 4 0}(0.07)$ & $-\mathbf{0 . 0 9 8}(0.00)$ & $-\mathbf{0 . 1 0 8}(0.03)$ & -2.06 & -35.9 \\
\hline 15 & Windfall-Hinton & $1961-2010$ & $-\mathbf{0 . 0 2 2}(0.00)$ & $-\mathbf{0 . 0 2 6}(0.00)$ & $-\mathbf{0 . 0 3 2}(0.00)$ & -1.11 & -54.2 \\
\hline 16 & Hinton-Jasper & 1970-2010 & -0.006 & 0.000 & 0.000 & -0.29 & -10.9 \\
\hline 17 & Combined 7-12 & 1976-1995 & -0.003 & 0.008 & 0.005 & -0.13 & -2.8 \\
\hline 18 & Lake Athabasca inflow & 1976-1995 & $-\mathbf{0 . 1 4 2}(0.03)$ & $-\mathbf{0 . 1 8 8}(0.00)$ & $-\mathbf{0 . 2 0 7}(0.10)$ & -7.22 & -21.2 \\
\hline 19 & Lake level (original) & 1960-2010 & $-\mathbf{0 . 0 0 8}(0.10)$ & $-\mathbf{0 . 0 0 6}(0.09)$ & -0.009 & -0.39 & -0.2 \\
\hline 20 & Lake level (adjusted) & 1960-2010 & $-\mathbf{0 . 0 1 7}(0.01)$ & $-\mathbf{0 . 0 1 3}(0.02)$ & -0.009 & -0.87 & -0.4 \\
\hline
\end{tabular}

periods are not significant even though there is a slight increase over 1970-2010 (Fig. 6). Trends and equivalent discharges in the small rivers, including MacFarlane, Douglas, Grease, Otherside, Richardson and William rivers, discharging to Lake Athabasca are summarized in Table 2. Similar to the Fond du Lac River, no regime shift or significant trends are found in the analysis of the small rivers time series. The MK test for the combined time series of the small tributaries shows that there are two increasing trends for periods of 1970-2010 and 1977-2010, but none of them is significant, and $p$ values are $\geq 0.10$ (Fig. 7). Together with the Fond du Lac River, other small rivers have increased lake input by $\sim 0.59 \mathrm{~km}^{3}$ over $1977-2010$, partially offsetting declines along the Athabasca River. There is a slight regime shift in the overall Lake Athabasca input detected in 1998 (Fig. 8), and a significant trend of $-0.142 \mathrm{~km}^{3} \mathrm{yr}^{-1}(p$ value $=0.03)$ from 1960 to 2010 according to the MK test. Over this $51 \mathrm{yr}$ period, total lake input has thus declined by $7.22 \mathrm{~km}^{3}$.

\section{Discussion}

\subsection{Regime shifts and trends in the Lake Athabasca basin}

Streamflows for the different gauges along the Athabasca River show a decreasing regime shift at downstream gauges from Athabasca to McMurray and no regime shift for the upstream reaches between the Jasper and Windfall gauges during the analysis period. The average contribution from the glacier sources in the Athabasca River discharge is $0.8 \%$ over 2000-2007 (Marshall et al., 2011). The gauge contribution of the drainage areas in between two immediate gauges in the Athabasca River does not indicate any regime shift, except for the area in between the Athabasca and Windfall gauges. The regime shift for the area between Hinton and Jasper is relatively too small in magnitude to call it a streamflow regime change. The largest downward shift for the gauge record belongs to the McMurray gauge. The other rivers (e.g., the Fond du Lac River and combination of the small rivers) experience no regime change during the last five decades.

To assess the streamflow regime change in relation to climate variability (Déry and Wood, 2005), we compared the regimes detected in the Athabasca River with those of the 

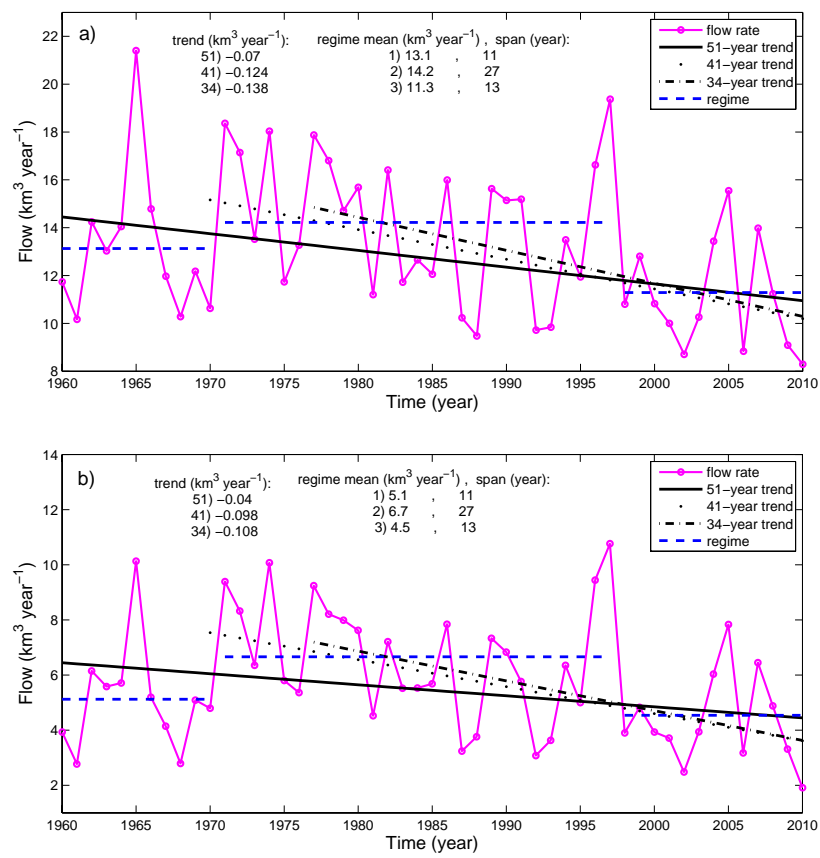

Fig. 4. Regime shifts and detected trends for three different analysis periods in (a) the Athabasca River near Athabasca and (b) the gauge contribution of the Athabasca River between the Athabasca and Windfall gauges. The trend levels for both time series are significant and decrease with the analysis periods moving towards the end of the study period, with their maximum (negative) trends over 1977-2010.

Pacific Decadal Oscillation (PDO) and Arctic Oscillation (AO) indices as two of the important climate indicators affecting the snowmelt rate and consequently the streamflow variability. The regime changes in the Athabasca River at the McMurray and Athabasca gauges as well as the lake input are detected in 1998, two decades after the regime change in PDO in 1977 ( $p$ value $=0.04)($ Rodionov, 2004) and one decade after the regime change in AO in 1988 ( $p$ value $=0.07$ ). The regime changes are assessed based on the annual PDO and AO averaged over January-December. A study by Burn (2008) showed that trends in streamflow correlate to temperature changes in the spring and to some extent to one or more climate indices, representing the fact that there is a possibility of climate change impact on the observed trends. To verify this in the study area, we conducted a correlation analysis and found significant correlations between mean and maximum air temperatures at the Fort McMurray meteorological station and total Lake Athabasca inflow $(\rho \leq-0.27)$ as well as the gauge record at Jasper $(\rho \leq$ -0.17 ). This supports the idea that part of the streamflow changes is due to climate change in the study area.

The magnitude of the trends varies markedly across the basin (Table 2). All gauge records indicate a modest decreasing trend in the headwaters of the Athabasca River and a strong decreasing trend at the McMurray gauge over the
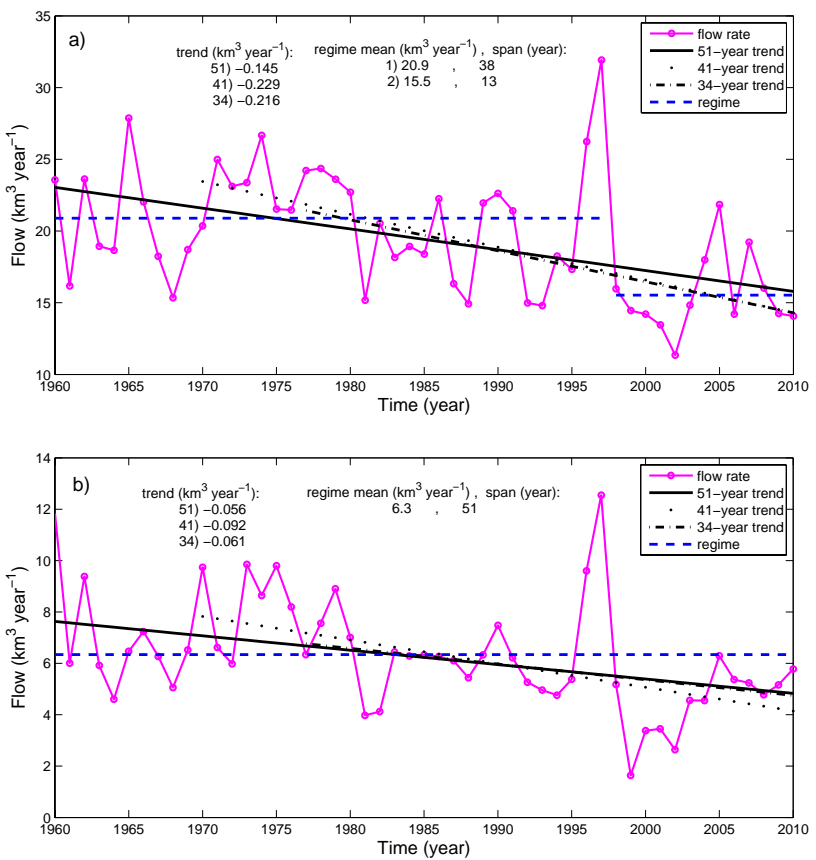

Fig. 5. Regime shifts and the detected trends for three different analysis periods for (a) the Athabasca River at McMurray and (b) the gauge contribution of the Athabasca River between the McMurray and Athabasca gauges. The trend levels for both time series are significant and decreasing, except for the period 1977-2010 for the contribution time series.

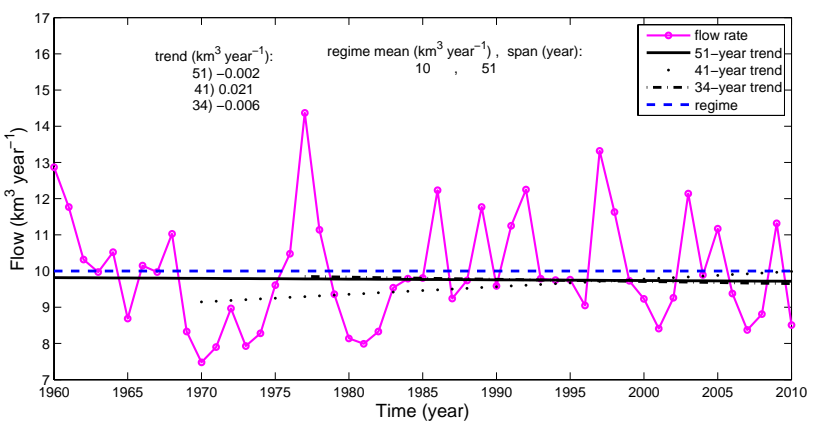

Fig. 6. Detected trends for three different analysis periods in Fond du Lac River. These trends are not significant ( $p$ value $\geq 0.10$ ).

last decades. The contribution from the gauges decreases and other tributaries with outlets to Lake Athabasca have an increasing trend during 1960-2010, attenuating downward shifts and decreasing trends along downstream reaches of the Athabasca River. Over the last $51 \mathrm{yr}$, the volume of lake inflow has declined $7.22 \mathrm{~km}^{3}$, which accounts for about $21.2 \%$ of annual average inflow in that period. The relative changes are $-26.9 \%$ and $-37.9 \%$ at the Athabasca and McMurray gauges. The analyses of variability of the Lake Athabasca inflow and detected trends and regime changes over 1960-2010 are assessed without consideration of their driving mechanisms. 


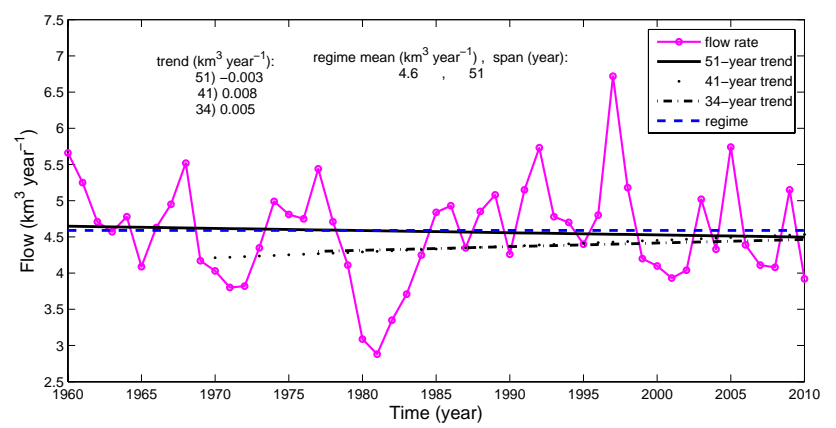

Fig. 7. Input flow rate to Lake Athabasca from other small rivers and the detected trends for three different analysis periods. These trends are not significant ( $p$ value $\geq 0.10$ ).

\subsection{Potential implications to water levels of Lake Athabasca}

Wolfe et al. (2011) report up to 2-4 m historical declines in Lake Athabasca levels in their $5200 \mathrm{yr}$ proxy data based on sediment cores compared to present-day conditions. Lake Athabasca has a surface area of about $7800 \mathrm{~km}^{2}$, implying this change in water level corresponds to a $15.6 \mathrm{~km}^{3}$ to $31.2 \mathrm{~km}^{3}$ change in lake volume. The MK trend detection method on the annual discharge data for the Athabasca River at McMurray yields a trend of $-0.145 \mathrm{~km}^{3} \mathrm{yr}^{-1}$ ( $p$ value $=0.02$ ), equivalent to a loss of $7.38 \mathrm{~km}^{3}$ in volume or a decline of about of $0.95 \mathrm{~m}$ in Lake Athabasca water level over 1960-2010. This matches our rough estimate of lake level changes from streamflow trends. The lake level data recorded near Crackingstone Point are investigated in order to evaluate possible regime and trend change. According to the Peace-Athabasca Delta Technical Study (PADTS, 1996; Wolfe et al., 2012), the combination of regulated Peace River flow and the outflow rock-fill weirs constructed permanently on the Rivière des Rochers in September 1975 and the Revillon Coupé in March 1976 has increased the average annual lake level at Crackingstone Point by about $0.33 \mathrm{~m}$ (calculated by averaging the monthly estimates in Table 1.4.1, PADTS, 1996). In the current study the recorded time series has been adjusted accordingly to account for this artificial increase in lake levels. Figure $9 \mathrm{a}$ and $\mathrm{b}$ illustrate the recorded and adjusted level time series of Lake Athabasca, respectively, over 1960-2010 with trends detected over the analysis periods. The actual trend rate (Fig. 9b) over 19602010 is $-0.017 \mathrm{~m} \mathrm{yr}^{-1}$ ( $p$ value $=0.01$, which is equivalent to a $0.87 \mathrm{~m}$ recession in the lake level. In addition, the lake average level has changed from $209.66 \mathrm{~m}$ over 1942 1967 to 208.89 m in 1972-1989 (Muzik, 1991; Bennett et al., 1973). Since there is a lack of quality in the available data before 1960 for all the gauges recording streamflow in the Lake Athabasca basin, we have conducted our analysis afterward. Taking into account the findings from Muzik (1991), it is expected that the lake level dropped by $\sim 1.64 \mathrm{~m}$ over

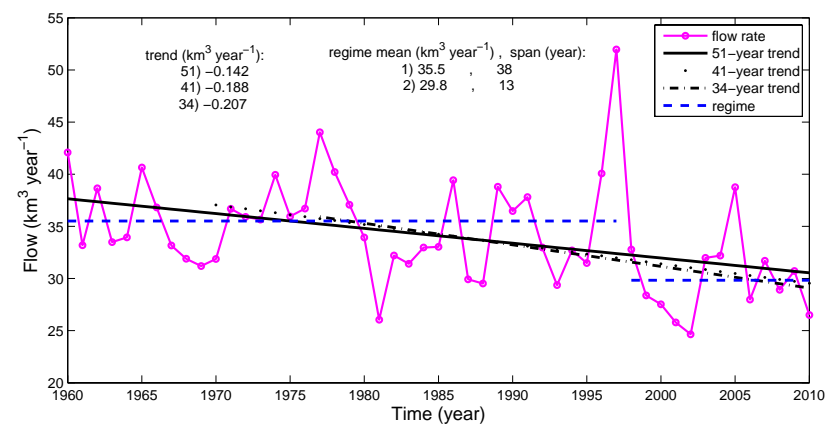

Fig. 8. Input flow rate to Lake Athabasca and the significant detected trends for three different analysis periods. These trends are significant with $p$ values of $0.10,0.00$, and 0.03 for analysis periods of 34,41 , and $51 \mathrm{yr}$, respectively.

1942-2010. The total lake inflow trend over $1977-2010$ is $-0.207 \mathrm{~km}^{3} \mathrm{yr}^{-1}$ ( $p$ value $=0.10$ ), equating to a reduction of $25.67 \mathrm{~km}^{3}$ in lake volume by 2100 if the linear trend persists. This leads to a possible 2-3 $\mathrm{m}$ further decline in the lake level considering the lake surface area. On the other hand, the in situ lake level data indicate a $2.40 \mathrm{~m}$ recession in the lake level, obtained by extrapolating the linear trend applied to the adjusted level data at the Crackingstone Point, by 2100 with a significance level of $p$ value $=0.01$. This value is in agreement with the lake level recession estimated through the reduced lake inflow and its surface. The streamflow decline observed on the Athabasca River at McMurray is slightly attenuated by an upward trend in discharge for the Fond du Lac River together with other small rivers of about $0.59 \mathrm{~km}^{3}$, equivalent to a few centimeters rise in lake level over 1977 2010. However, it should be noted that this attenuation is not significant. The analyses over 1977-2010 are mainly conducted on the observed data, which are more reliable and avoid the uncertainty inserted in the reconstruction of the time series for gauges on the smaller rivers.

The highlands of the Athabasca River (e.g., near Jasper) are fed both with abundant snowmelt and seasonal glacier ablation from high elevations of the Rocky Mountains, which intensifies in the summer and results in high flows then (Woo and Thorne, 2003). Projections of future changes in Rocky Mountain rivers suggest that the predicted summer flows in 2005-2055 may decline considerably, while winter and early spring flows may increase, resulting in $\sim 3-9 \%$ decline in the annual discharge (Shepherd et al., 2010). Generally under warming scenarios, winter flows will increase, the spring freshet dates will advance, but peak flows will decline (Woo et al., 2008). Climatic changes, land cover/use changes, and enhanced water extractions for various societal and commercial needs including the oil sands development near Fort McMurray, which is projected to increase by $200 \%$ by 2015 (Pavelsky and Smith, 2008), may continue to decrease Lake Athabasca inflow rates. Ignoring changes in vertical water fluxes over the lake (e.g., precipitation, 

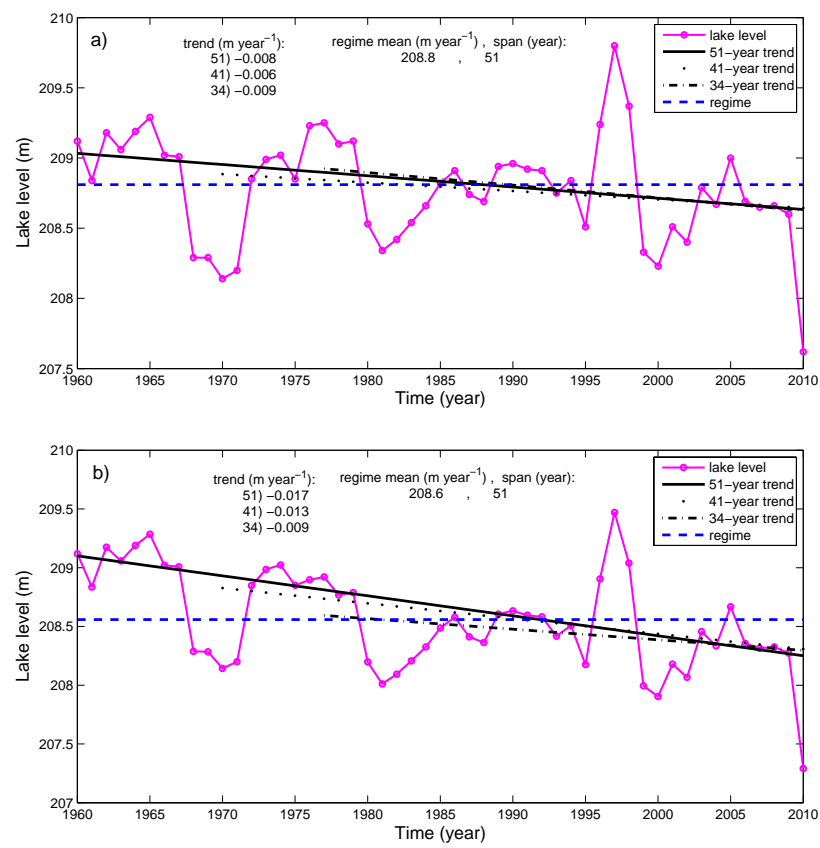

Fig. 9. Level of Lake Athabasca (original) and the detected trends based on (a) original recorded data near Crackingstone Point and (b) data adjusted to account for the artificial increase in recorded levels. The significance levels ( $p$ values) are less than 0.02 for the adjusted lake level for the analysis periods of $41 \mathrm{yr}$ and $51 \mathrm{yr}$.

evaporation, and infiltration) and in lake outflow, the monotonic, decreasing trend in total lake inflow obtained in this study suggests that by 2100 the lake level may drop by 2 to $3 \mathrm{~m}$, which is within the range of $2-4 \mathrm{~m}$ of the $5200 \mathrm{yr}$ historical minimum inferred from a sediment proxy record of the lake's level (Wolfe et al., 2011) and would exacerbate water shortages in the area.

\section{Conclusions}

In the present study, the 1960-2010 variability and trends of streamflow input to Lake Athabasca, irrespective of causal factors, were investigated using two robust tests: the nonparametric Mann-Kendall test developed by Mann (1945) and Kendall (1975) and a regime shift detection method by Rodionov (2004). The results showed that there are significant trends in the principal downstream reaches of the Athabasca River leading to a $7.22 \mathrm{~km}^{3}$ reduction in total streamflow input and a $0.87 \mathrm{~m}$ decline in the level of Lake Athabasca over the study period. Although rising air temperatures have led to higher peak waters in glacierized watersheds such as the Athabasca River at Jasper, we found a decreasing trend of $0.005 \mathrm{~km}^{3} \mathrm{yr}^{-1}$ with a $p$ value of 0.03 at this gauge. A previous analysis of streamflow trends in glacier-fed basins of British Columbia, Canada, suggested that should the current warming rate continue, glaciers will recede and summer flows will decrease even further (Stahl and Moore, 2006). An increase in the flow rate in the Fond du Lac River, the second largest contributor to total lake inflow, has partially offset recent lake level reductions; however, this trend is relatively smaller in magnitude than the overall downward trend to total lake inflow. The methods successfully applied in the present study are easily transferable to other lake basins worldwide where observational or simulated streamflow data are readily available, such as the rapidly shrinking Lake Urmia (Garousi et al., 2013), Lake Chad (Gao et al., 2011) and Aral Sea (Micklin, 2007).

Future work on the changing hydrology of Lake Athabasca drainage should consider establishing the driving mechanisms leading to changes in streamflow generation across all of the watershed's main reaches. In addition, a comprehensive water budget study examining atmospheric moisture fluxes, precipitation amounts and phases, and evapotranspiration rates over the basin, as well as long-term changes in freshwater storage such as in glaciers, requires immediate attention to better project future Lake Athabasca levels and downstream impacts. This research is particularly urgent as water extractions for potable water and domestic use in communities, irrigation for agriculture, and industrial oil sands production (the second largest proven petroleum reserves globally after Saudi Arabia; Pavelsky and Smith, 2008; Swart and Weaver, 2012) in the Athabasca drainage intensify in the coming decades. Thus, continued monitoring and analysis of streamflow input to Lake Athabasca will remain a priority as climate change and anthropogenic activities both accelerate into the 21st century. This will have substantial impacts on the flora and fauna of the basin, most notably in the ecologically sensitive Peace-Athabasca Delta, the world's largest inland delta that forms a critical habitat for wildlife (e.g., the world's largest herd of wood bison) and a staging area for massive bird migrations (such as ducks, geese, swan and endangered whooping cranes).

Acknowledgements. Thanks to Roland Hall (University of Waterloo) and Brent Wolfe (Wilfrid Laurier University) for motivating this study, and Tom Edwards, Donald H. Burn (both at the University of Waterloo), John Johnston (University of Toronto Mississauga), and David Schindler (University of Alberta), as well as all reviewers, for very insightful comments on this paper. Funding provided by the government of Canada's CRC program to SJD and an NSERC Discovery Grant to SJD.

Edited by: A. Ghadouani 


\section{References}

Abdul Aziz, O. I. and Burn, D. H.: Trends and variability in the hydrological regime of the Mackenzie River Basin, J. Hydrol., 319, 282-294, 2006.

Bennett, R. M., Card, J. R., and Hornby, D. M.: Hydrology of Lake Athabasca: Past, Present and future, Hydrol. Sci. Bul., 18, 337345, doi:10.1080/02626667309494045, 1973.

Burn, D. H.: Climatic influences on streamflow timing in the headwaters of the Mackenzie River Basin, J. Hydrol., 352, 225-238, 2008.

Burn, D. H., Abdul Aziz, O. I., and Pietroniro, A.: A comparison of trends in hydrological variables for two watersheds in the Mackenzie River Basin, Can. Wat. Resour. J., 29, 283-298, 2004.

Déry, S. J. and Wood, E. F.: Decreasing river discharge in northern Canada, Geophys. Res. Lett., 32, L10401, doi:10.1029/2005GL022845, 2005.

Déry, S. J., Stieglitz, M., McKenna, E. C., and Wood, E. F.: Characteristics and trends of river discharge into Hudson, James, and Ungava Bays, 1964-2000, J. Climate, 18, 2540-2557, 2005.

Déry, S. J., Hernández-Henríquez, M. A., Owens, P. N., Parkes, M. W., and Petticrew, E. L.: A century of hydrological variability and trends in the Fraser River Basin, Environ. Res. Lett., 7, 024019, doi:10.1088/1748-9326/7/2/024019, 2012.

Gao, H., Bohn, T. J., Podest, E., McDonald, K. C., and Lettenmaier, D. P.: On the causes of the shrinking of Lake Chad, Environ. Res. Lett., 6, 034021, doi:10.1088/1748-9326/6/3/034021, 2011.

Garousi, V., Najafi, A., Samadi, A., Rasouli, K., and Khanaliloo, B.: Environmental crisis in Lake Urmia, Iran: a systematic review of causes, negative consequences and possible solutions, Proc. of the 6th Int. Perspec. On Water Resour. and the Env., Izmir, Turkey, January 2013, EWRI, 10, 2013.

Hamed, K. H. and Rao, A. R.: A modified Mann-Kendall trend test for autocorrelated data, J. Hydrol., 204, 182-196, 1998.

Jordaan, S. M., Keith, D. W., and Stelfox, B.: Quantifying land use of oil sands production: A life cycle perspective, Environ. Res. Lett., 4, 024004, doi:10.1088/1748-9326/4/2/024004, 2009.

Kendall, M. G.: Rank Correlation Methods, Charles Griffin, London, 160 pp., 1975.

Mann, H. B.: Nonparametric tests against trend, Econometrica, 13, 245-259, 1945.

Marshall, S. J., White, E. C., Demuth, M. N., Bolch, T., Wheate, R., Menounos, B., Beedle, M., and Shea, J. M.: Glacier water resources on the eastern slopes of the Canadian Rocky Mountains, Can. Water Resour. J., 36, 109-134, 2011.

McClelland, J. W., Déry, S. J., Peterson, B. J., Holmes, R. M., and Wood, E. F.: A Pan-Arctic evaluation of changes in river discharge during the latter half of the 20th century, Geophys. Res. Lett., 33, L06715, doi:10.1029/2006GL025753, 2006.

Micklin, P.: The Aral Sea disaster, Annu. Rev. Earth Planet. Sc., 35, 47-72, 2007.

Muzik, I.: Hydrology of Lake Athabasca, Hydrology of Natural and Manmade Lakes, Proc. of the Vienna Symposium, August 1991, IAHS-AISH P., 226, 13-22, 1991.

Orcutt, G. H. and Winokur Jr., H. S.: Autoregression: Inference, estimation, and prediction, Econometrica, 37, 1-14, 1969.

Pavelsky, T. M. and Smith, L. C.: Remote sensing of hydrologic recharge in the Peace-Athabasca Delta, Canada, Geophys. Res. Lett., 35, L08403, doi:10.1029/2008GL033268, 2008.
Peace-Athabasca Delta Technical Studies (PADTS): Final Report. PADTS Steering Committee, Fort Chipewyan, Alberta, 106 pp., 1996.

Peters, D. L. and Buttle, J. M.: The effects of flow regulation and climatic variability on obstructed drainage and reverse flow contribution in a northern river-lake-delta complex, Mackenzie basin headwaters, River Res. Appl., 26, 1065-1089, 2010.

Peters, D. L., Prowse, T. D., Pietroniro, A., and Leconte, R.: Flood hydrology of the Peace-Athabasca Delta, northern Canada, Hydrol. Process., 20, 4073-4096, 2006.

Rodionov, S. N.: A sequential algorithm for testing climate regime shifts, Geophy. Res. Lett., 31, L09204, doi:10.1029/2004GL019448, 2004.

Rood, S. B., Pan, J., Gill, K. M., Franks, C. G., Samuelson, G. M., and Shepherd, A.: Declining summer flow of Rocky Mountain rivers: Changing seasonal hydrology and probable impacts on floodplain forests, J. Hydrol., 349, 397-410, 2008.

Schindler, D. W. and Donahue, W. F.: An impending water crisis in Canada's western prairie provinces, P. Natl. Acad. Sci., 103, 7210-7216, 2006.

Sen P. K.: Estimates of the regression coefficient based on Kendall's tau, J. Am. Stat. Assoc., 63, 1379-1389, 1968.

Shepherd, A., Gill, K. M., and Rood, S. B.: Climate change and future flows of Rocky Mountain rivers: converging forecasts from empirical trend projection and down-scaled global circulation modeling, Hydrol. Process., 24, 3864-3877, 2010.

Smith, L. C. and Pavelsky, T. M.: Remote sensing of volumetric storage changes in lakes, Earth Surf. Proc. Land., 34, 1353-1358, 2009.

Stahl, K. and Moore, R. D.: Influence of watershed glacier coverage on summer streamflow in British Columbia, Canada, Water Resour. Res., 42, W06201, doi:10.1029/2006WR005022, 2006.

Swart, N. C. and Weaver, A. J.: The Alberta oil sands and climate, Nature Climate Change, 2, 134-136, 2012.

Theil, H.: A rank-invariant method of linear and polynomial regression analysis, I. Nederlands Akad. Wetensch. Proc., 53, 386-392, 1950a.

Theil, H.: A rank-invariant method of linear and polynomial regression analysis, II. Nederlands Akad. Wetensch. Proc., 53, 521525, 1950b.

Theil, H.: A rank-invariant method of linear and polynomial regression analysis, III. Nederlands Akad. Wetensch. Proc., 53, 13971412, 1950c.

Von Storch, V. H.: Misuses of statistical analysis in climate research. In Analysis of Climate Variability: Applications of Statistical Techniques, edited by: von Storch, H. and Navarra, A., SpringerVerlag: Berlin, 11-26, 1995.

Wolfe, B. B., Hall, R. I., Edwards, T. W. D., Jarvis, S. R., Niloshini Sinnatamby, R., Yi, Y., and Johnston, J. W.: Climate-driven shifts in quantity and seasonality of river discharge over the past 1000 years from the hydrogeographic apex of North America, Geophys. Res. Lett., 35, L24402, doi:10.1029/2008GL036125, 2008a.

Wolfe, B. B., Hall, R. I., Edwards, T. W. D., Vardy, S. R., Falcone, M. D., Sjunneskog, C., Sylvestre, F., McGowan, S., Leavitt, P. R., and van Driel, P.: Hydroecological responses of the Athabasca Delta, Canada, to changes in river flow and climate during the 20th century, Ecohydrology, 1, 131-148, 2008 b. 
Wolfe, B. B., Edwards, T. W. D., Hall, R. I., and Johnston, J. W.: A 5200-year record of freshwater availability for regions in western North America fed by high-elevation runoff, Geophys. Res. Lett., 38, L11404, doi:10.1029/2011GL047599, 2011.

Wolfe, B. B., Hall, R. I., Edwards, T. W. D., and Johnston, J. W.: Developing temporal hydroecological perspectives to inform stewardship of a northern floodplain landscape subject to multiple stressors: paleolimnological investigations of the Peace-Athabasca Delta, Environ. Rev., 20, 191-210, doi:10.1139/A2012-008, 2012.
Woo, M. and Thorne, R.: Streamflow in the Mackenzie Basin, Canada, Arctic, 56, 328-340, 2003.

Woo, M., Thorne, R., Szeto, K., and Yang, D.: Streamflow hydrology in the boreal region under the influences of climate and human interference, Philos. Trans. R. Soc. B., 363, 2251-2260, 2008.

Yue, S., Pilon, P. J., Phinney, B., and Cavadias, G.: The influence of autocorrelation on the ability to detect trend in hydrological series, Hydrol. Process., 16, 1807-1829, 2002. 